J. Korean Soc. Math. Ed. Ser. A: The Mathematical Education November. 2013, Vol. 52, No. 4, 549-565.

증명에서 연역 체계 이해에 관한 연구

강정기(창원남산중학교)

노은환(진주교육대학교 $)^{+}$

\section{I. 서론}

증명은 수학적 사고의 근간을 이루는 추론과 정당화 를 보여주는 대표적인 사고 활동이므로 학교수학에서도 증명 교육은 지속적으로 강조되고 있다. 뿐만 아니라 증 명은 학생들의 수학적 이해를 촉진시키는 중요한 역할을 담당하는 것으로 알려져 있다(Hanna, 2000). 수학은 본 질적으로 증명에 관한 학문이며(Almeida, 1996), 증명은 수학을 행하고 의사소통하며 기록하는 활동의 핵심으로 수학과 분리될 수 없을 정도로 수학에서 매우 중요한 위 치를 차지하고 있다(Schoenfeld, 1994).

이러한 증명은 그리스인들이 창안한 '공리로부터의 연역'이 그 시발점이 되었으며 오늘날까지 그 면면을 이 어가고 있다. 그리스인들은 '공리로부터의 연역'이라는 방법을 창안하여, 기하학을 경험적 학문에서 연역적 학 문으로 바꾸어 놓았다. 유클리드 《원론》의 연역적 전 개는, 어떤 기하학적 명제가 경험적으로는 참일 수 있으 나 그것의 수학적 정당화는 경험에 의존하지 않는다는 것을 명확히 하였다(이지현, 2011).

여기서 연역의 출발점인 공리의 결정은 고도의 수학 적 지식을 필요로 한다. 수학의 역사 속에서 있어왔던 유클리드의 평행공리에 관한 심각했던 갈등이 이를 잘 보여준다. 많은 수학자들은 자명해 보이지만 공리로서의 기능에 의심을 가지고 평행공리를 다른 공리로부터 증명 하고자 시도하였지만, 이것은 실패로 끝났으며 비유클리 드 기하학의 출현을 야기하게 되었다. 비유클리드 기하

* 접수일(2012년 10월 31일), 수정일(2012년 12월 26일), 게재확 정일(2013년 01월 25일)

* ZDM분류 : D53

* MSC2000분류 : 97D50

* 주제어 : 연역 체계 이해, 연역의 출발점에 대한 필요성 인식, 순환 논법

† 교신저자
학의 출현은 어떤 체계에서 한 명제의 공리 혹은 정리의 지위를 결정하는 것은 그 명제가 가진 자명성의 정도가 아니라 바로 “그 명제가 체계의 다른 명제들과 독립인 가?”라는 것이 초점이 되어야 한다는 사실이 밝혀진 계 기가 되었다(Dodes, 1966).

이후 공리에 대한 논쟁이 가속화되었으며, Hilbert는 관계들 속에서 암묵적으로 정의되는 무정의 용어를 기반 으로 한 공리계를 발표하기에 이러게 된다. 그러나 Frege는 공리들은 진리를 표현해야 하고 정의들은 특정 용어들의 의미를 부여하여 그 외연을 확장해야 하는 것 으로, 암묵적 정의는 어느 것도 성취할 수 없다고 하여 Hilbert의 공리계를 비판하기도 하였다(박우석, 2008). 이 외에도 많은 논쟁이 있어왔지만, 오늘날 많은 학자들은 공리의 최소의 충족요건으로서 무모순성, 완전성, 독립성 을 들고 있다.1)

수학 역사에서 공리 선택에 대한 철학적 논쟁은 연역 체계의 기초를 확립하고자하는 것으로, 그 내용이 심오 하여 이해하기 쉽지 않다. 따라서 이 내용을 학교 수학 에서 여과 없이 지도하는 것은 바람직하지 못할 것으로 생각된다. 그러나 연역 체계의 기초 확립을 추구한 공리 에 대한 논쟁의 근저에는 연역 체계에 대한 이해가 수반 되어 있으며, 연역 체계의 이해는 증명 교육이 추구하는 목표 중 하나일 것이다.

Fawcett(1966)은 연역적 증명의 본질을 이해하는 것 이 곧 증명 교육의 목적이며, 학생이 무정의 개념의 의

\footnotetext{
1) 주어진 공리계를 $S$ 라고 하고 그 공리계에 포함된 공리들을 $p_{1}, p_{2}, \cdots, p_{n}$ 이라고 하자. 공리계가 무모순이라는 것은 $S$ 에 의한 수학적 체계상에 있는 어떤 참인 명제들도 서로 모 순되지 않는다는 것을 말한다. 어떤 공리계 $S$ 가 독립이라는 것은 어떤 $n-1$ 개의 공리 $p_{i}$ 들도 나머지 $p_{s}$ 를 증명할 수 없다는 것을 말한다. 어떤 공리계가 완전하다는 것은 그 공 리체계로부터 나온 수학적 체계의 모든 명제를 증명 또는 반증할 수 있다는 것을 말한다(유윤재, 2004).
} 
미와 역할을 이해하며, 명확하게 정의된 용어의 필요성 과 그것이 결론에 미치는 영향을 이해하며, 또한 가정 또는 증명되지 않는 명제가 필요하며, 아울러 가정이 함 축하지 않는 것을 증명하는 경우는 없다는 것을 이해하 는 것이 연역적 증명의 본질을 이해하는 것이라고 하였 다. 그는 이것을 이해하지 못한다면 논거와 결론이 혼재 된 순환논법의 오류를 피하지 못하게 된다고 언급하고 있다. Fawcett(1966)이 언급한 증명의 본질 중 한 가지 는 연역 체계에 내재된 성격을 이해하는 것으로 볼 수 있을 것이다.

연역 체계는 증명의 근간을 이루는 무정의 용어와 정 의 및 공리를 필요로 하며, 이들 근거로부터 일방향의 연역 흐름을 통해 정리 증명에 도달하는 것을 추구하는 것이다. 이와 같은 연역 체계가 갖는 성격에 대한 이해 는 하나의 정리 증명에 대한 고찰을 통해 도달하기 어렵 다. 연역 체계에 대한 이해는 여러 정리 증명을 조망하 는 가운데, 논리의 시발점이 되는 근거인 공리의 필요성 을 인식하고, 또 정리들 간의 연역 체계의 흐름을 인식 할 수 있을 때 가능한 이야기이다. 즉, 순환 논법 때문에 발생할 수 있는 오류를 연역 체계의 흐름 속에서 인식할 수 있어야 한다.

그러나 정리 증명에만 주목하여 연역 체계 전체를 조 망하기 어려운 학생들의 입장에서 논리의 시발점에 대한 필요성과 일방향을 지향하는 연역 체계의 흐름을 인식하 기란 쉽지 않은 일로 생각된다. 비록 하나의 정리 증명 은 잘 수행하지만, 정리가 포함된 연역 체계 전체가 논 리 시발점을 필두로 어떤 흐름으로 전개되는지를 파악하 지 못한다면 그리스인들로부터 시작된 '공리로부터의 연 역'을 제대로 이해하기 어려울 것이다. Fawcett(1966)의 주장에서 보듯, 이와 같은 연역 체계의 성격을 이해하지 못한다면 증명의 본질을 이해하지 못한 체 증명을 학습 하는 것이 된다.

이에 본 연구에서는 증명을 학습할 수준을 갖춘 학생 들이 연역 체계에 함의된 주요 특성인 논리의 시발점에 대한 필요성과 일방향의 연역 흐름을 이해할 수 있도록 돕는 것을 목적으로 한다. 이를 위해 먼저, 교과서 연역 체계의 특성을 파악해 보고자 한다. 교과서를 분석해 봄 으로써 연역 체계가 교과서에 어떻게 반영되어 있는지를 파악하고자 한다. 또한 현 교과 체제에서 오류라고 지목
되는 순환 논법의 구체적 예를 찾고 분석해 봄으로써 연 역 체계 흐름의 특성을 명료화하고자 한다. 이러한 교과 서 분석과 순환 논법의 오류 분석을 통해 파악된 교과서 연역 체계의 특성을 바탕으로 연역 체계에 대한 바람직 한 지도 방향을 탐색하고자 한다. 궁극적으로 공리적 사 고의 정신을 이해하는 기초를 마련하고자 한다.

\section{II. 이론적 배경}

본 장에서는 증명에 관한 연구를 조망해 봄으로써, 이들 연구 속에서 연역 체계의 이해가 갖는 위치를 가늠 해보고자 한다. 증명에 관한 연구는 크게 증명의 본질과 역할에 관한 연구, 증명의 실제에 관한 연구, 증명의 지 도에 관한 연구로 구분해 볼 수 있다.

먼저, 증명의 본질과 역할에 관한 연구에 대해 살펴 보기로 하자. 증명이란 무엇인가? 증명의 본질에 대한 이 물음의 답은 수리철학의 입장에 따라 달라질 수 있 다. 수학적 지식의 본질에 대한 입장은 크게 절대주의와 상대주의로 구분된다. 수학적 지식을 절대적인 것으로 간주한 플라톤주의가 비유클리드 기하의 탄생으로 동요 하게 되었고, 이 현상을 극복하기 위한 논의로 19 세기와 20 세기 초에 논리주의, 형식주의, 직관주의가 대두하게 되었다. 이들 절대주의 사조는 관점의 차이가 있기는 하 지만, 공통적으로 증명의 본질을 수학적 명제를 정당화 하는 수단으로서 파악하고 있다. 그러나 20세기에 들어 절대주의 사조에 대한 비판으로 준경험주의, 사회적 구 성주의가 대두되었다. Lakatos로 대표되는 준경험주의에 서 증명은 추측을 반박하여 개선하게 하는 발견의 수단 이며, 수학적 지식을 사회적 구성물로서 받아들이는 사 회적 구성주의에서 증명은 자신뿐 아니라 타인을 이해시 키고 확신시키는 수단이다(나귀수, 1998).

일반적으로 대다수의 수학자들은 Lakatos의 관점을 지지하지 않으며, 절대주의, 특히 형식주의를 지향하는 반면(Sierpinska \& Lerman, 1996), 수학교육자들은 대조 적으로 Lakatos의 준경험주의 수리철학에 많은 호응을 하는 편이다(강문봉, 1993; 나귀수, 1998; Lehman, 1980). 이는 학자별 입장과 신념에 따라 증명의 본질에 관한 다 양한 관점이 존재함을 시사한다.

증명의 본질에 대한 다양한 입장은 증명이 학교수학 
에서 다면적인 역할을 하는 것과 연결된다. Bell(1976, 1979)은 증명을 가상의 의심을 품은 상대(imaginary doubter)를 대상으로 내적으로 행해지는 것이며, 본질적 으로 확신이 뒤 따르게 되는 공적 활동으로 묘사하였다. 그는 증명을 세 가지 의미를 이행하는 것으로 보았다. 첫째, 입증(verification)이나 정당화(justification)이다. 이 것은 명제의 참과 관련된 것을 말한다. 둘째, 조명 (illumination)이다. 이것은 명제가 왜 참이며 거짓인지에 대한 통찰을 전달하는 것을 의미한다. 셋째, 체계화 (systematisation)이다. 이것은 공리, 더 큰 개념과 정리 의 연역 체계로 결과들을 조직하는 것을 말한다.

De Villiers는 Bell이 제시한 증명의 세 가지 역할 이 외에 발견과 의사소통의 역할을 추가하여 입증, 설명, 체 계화, 발견, 의사소통 5 가지를 들고 있다(류성림, 1998b). 이것은 증명을 다면적으로 이해하고 접근해야 함을 시사 한다. 이상에서 살펴본 증명의 본질과 그 역할에 대한 논의는 수학교육에서 증명 그 자체에 대한 연구로 볼 수 있을 것이다.

증명에 관한 다른 연구로 증명의 실제에 관한 것이 있다. 교사는 어떻게 증명을 인식하고 이를 지도하는지, 학생은 증명을 어떤 식으로 받아들이고 행하는지에 관한 문제이다. 이에 대한 대표적 연구로 Harel \& Sowder (1998)의 증명 스키마(proof schema)를 들 수 있다. 증명 스키마는 자기 자신이 참임을 확인하기 위해 사용하는 것과 다른 사람을 설득하기 위해 사용하는 모든 것이다. 그들은 선행 연구 결과를 종합하면서 증명 스키마를 외 부적 확신 증명 스키마(external conviction proof schemes), 경험적 증명 스키마(empirical proof schemes), 분석적 증명 스키마(analytical proof schemes)로 크게 구분하였다. 외부적 확신 증명 스키마 는 증명의 근거가 권위나, 형식, 기호 표현 등 외부적 출 처에 의존하는 것을 의미한다. 경험적 증명 스키마는 경 험적 증거에 기초한 주장을 강조하는 경우를 말한다. 분 석적 증명 스키마는 기본적으로 타당한 수학적 증명을 하는 경우를 의미한다.

Harel \& Sowder(1998)는 이와 같은 증명 스키마가 고정된 것이 아니라, 상황 의존적임을 지적하고 있다. 이 를테면, 교사가 대학원 입학시험에 임할 경우, 그는 분석 적 증명 스키마를 주로 사용할 수 있다. 그러나 그가 학
교에서 하위권 학생들을 지도할 경우, 그는 수업에서 경 험적 증명 스키마를 주로 사용할 수 있을 것이다. 이처 럼 증명 스키마는 고정된 것이 아니라 상황에 따라 유동 적인 것이다.

또한 주체가 갖는 증명 스키마에 의해 증명은 제각기 다른 표현 양식으로 나타날 수 있다. 박은조, 방정숙 (2005)은 선행 연구를 토대로 증명의 표현 양식을 경험 적 증명, 해설적 증명, 형식적 증명으로 분류하였다. 경 험적 증명은 구체적인 실증이나 경험이 특징인 증명 표 현 양식을 일컨는다. 해설적 증명은 일상적인 용어를 사 용하여 해설적으로 근거가 되는 이유와 설명을 제시한 증명이다. 형식적 증명은 가정과 결론간의 명백한 연계 를 가진 논리적 주장을 제시하며 기호를 사용한 증명을 일컫는다.

한편, 학생들은 증명이 왜 필요한지도 이해하지 못하 면서 증명을 학습하는 경우가 종종 있다. 또한 수행된 증명이 갖는 의미를 이해하기 어려워한다. 증명의 필요 성과 의미에 대한 이해 부족은 여러 연구에서 보고되고 있다(류성림, 1998a; Fischbein \& Kedem, 1982; Martin \& Harel, 1989; Williams, 1990).

이것은 증명의 의의에 대한 인식의 부족에서 비롯된 것으로 볼 수 있다. 이에 대해 Williams(1990)는 캐나다 의 11 학년 학생 225 명을 대상으로 증명의 의의에 대한 인식을 조사하였는데, 조사 결과 $50 \%$ 정도가 자명한 명 제를 증명하는 필요성을 느끼지 못하고, 또한 $70 \%$ 이상 의 학생들이 귀납적 추론이 수학적 일반화에 대해 부적 합하다는 사실을 인식하지 못하였으며, $80 \%$ 정도의 학 생들은 수학적 논쟁에서 가정과 정의의 의미를 전혀 이 해하지 못하였다. Fischbein \& Kedem(1982)와 Martin \& Harel(1989) 역시 이와 유사한 결론을 보여주고 있다. 국내에서도 류성림(1998a)이 국내학생들을 대상으로 증 명의 의의에 대한 인식의 부족을 보고한 바 있다.

이와 같은 증명의 의의에 대한 이해의 어려움은 증명 이 복합적 측면을 함의하고 있기에 빚어지는 현상으로 생각된다. 國宗進(1992)은 '증명의 의의'를 지도의 관점에 서 다음과 같이 제시하고 있으며(류성림, 1998a 재인용), 이는 증명의 의의의 복합적 측면을 보여준다. 
A. '증명의 일반성'을 이해시킨다.

(1) 정리는 전칭명제라는 것의 이해

(2) 증명에는 일반성이 있다는 것의 이해

(3) 도형의 일반성의 이해

(4) 실험, 실측에 의한 방법의 특징의 이해

B. '추론의 구성'을 이해시킨다.

(1) 가정·결론, 증명의 이해

(2) 근거가 되는 내용, 정의의 의미를 이해

(3) 순환 논법이 불합리하다는 것의 이해

(4) 체계의 이해

증명을 올바르게 이해하기 위해서는 이들 요소를 통 합적으로 이해할 필요가 있다. 어느 한 요소의 이해가 결여된다면 그것은 불완전한 이해에 그칠 수밖에 없다. 정리는 전칭명제라는 것을 이해하지만 도형의 일반성을 이해하지 못한다면, 제시된 증명을 특수한 도형에 대한 증명으로 인식할 수 있을 것이다.

한편, 國宗進(1992)은 증명의 의의에 대한 이해의 발 달 단계를 다음과 같이 구분하고 있다(류성림, $1998 \mathrm{a}$ 재 인용).

제 1 단계: 도형의 성질을 증명할 때, 실험·실측에 의 한 방법으로도 충분하다고 생각하는 단계

제 2단계: 연역적인 증명을 하지 않으면 안 되는 의 미를 이해하고 있는 단계

제 3 단계: 체계의 의미를 이해하면서 증명을 할 수 있는 단계

위 발달 단계에서 최상위 수준의 단계로서 체계의 의 미 이해가 제시되고 있으며, 이는 증명 이해의 정점이라 고 할 수 있다. 불충분한 경험적 정당화에 대한 보완으 로 연역적인 증명의 필요성을 인식할지라도 그것만으로 증명의 의의의 전부를 이해했다고 보기 어렵다. 증명의 의의를 완전하게 이해하기 위해서는 체계의 의미 이해가 수반되어야 한다.

이에 본 연구에서는 증명의 의의 이해의 최고 단계인 체계의 이해를 주제로 논의하고자 하는 것이다. 이러한 논의를 위해서는 무엇보다 연역 체계의 이해가 무엇인지 를 명확히 해야 할 것이다. 연역의 출발점으로서 공리의 필요성을 인식하고, 또 공리로부터의 연역이야 말로 유 클리드 연역 체계가 갖는 훌륭한 특징이다. 본 연구에서 연역 체계의 이해란, 이와 같은 특징을 이해하는 것을
의미한다. 증명 실제에 관한 선행 연구들이 연역 체계 이해를 거의 다루지 않았음을 주지해 볼 때, 본 연구는 기존의 연구와 차별된다.

마지막으로 증명의 지도에 관한 대표적 방법으로 분 석법이 제안되어 왔다(강문봉, 1992; 나귀수, 1998; Heath, 1981). 증명의 서술 방식이 종합적 양식2)을 따름 으로써 학생들이 진정한 ‘증명 활동'을 경험하지 못하고 '증명의 기록'만을 학습한다는 점으로 비판받아 왔으며, 이에 대한 대안으로 제시된 것이 분석법이다. 분석법은 종합적 양식의 역의 과정으로 결론으로부터 거꾸로 추론 하는 과정이다. 분석법은 찾고 있는 것을 마치 인정된 것처럼 여기고 그로부터 잇따른 결과를 거쳐 종합의 결 과로 인정되는 것까지 나아가는 방법이다(나귀수, 2009). 분석법을 제안하는 연구는 분석법을 통해 증명의 방법을 찾는 과정이 선행되어야 하며, 이후 발견된 방법을 종합 적 양식으로 기술되어야 한다고 주장한다.

또 하나의 대안은 경험적 정당화에서 형식적 증명으 로의 비약적인 도약을 완화할 목적으로 전형식적 증명 (preformal proof)을 제안하고 있다. 전형식적 증명은 형 식화 이전의 단계에서 '증명하는 활동'을 중요시하여 다 룰 필요에 의해 제안된 것으로, 증명의 아이디어 생성과 해석에 주안점을 둔 것이다. 이러한 전형식적 증명은 조 작적 기학적 표현과 결부되었으며, 일반적인 근거에 의 한 전략의 인식이 가능하며, 적절한 범례 또는 모델 내 에서의 증명(류성림, 1998c)이라는 특징을 갖고 있다. 이 를테면, 임의의 두 3 의 배수 합이 3 의 배수라는 명제 증 명에서 다음과 같은 범례에 의한 기하 조작은 전형식적 증명에 해당한다.

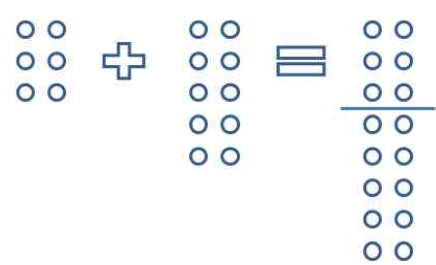

2) 종합적 양식이란, 수학에서의 증명 서술 양식으로, 증명 발견 과는 무관하게 오직 논리적으로 선후 관계를 따져 기술하는 방식을 뜻한다. 
이외에도 증명보조카드를 활용한 지도(조정수, 이정 자, 2006) 등 증명의 지도에 관한 여러 연구가 있기도 하다. 증명보조카드는 명제를 세분화하여 분석하고, 증명 의 방향을 스스로 탐구하는데 도움을 제공하는 보조적인 역할을 하는 카드로서 명제의 증명에 이용 가능한 정리 가 기록된 카드이다. 조정수, 이정자(2006)는 이 카드를 활용한 지도를 통해 긍정적인 증명 학습을 유도하기도 하였다.

이상에서 증명과 관련된 연구를 살펴보았는데, 이들 은 증명의 본질과 역할에 관한 연구, 증명의 실제에 관 한 연구, 증명의 지도에 관한 연구로 나누어 볼 수 있었 다. 여기서 연역 체계의 이해는 증명의 실제에 관한 연 구이며, 증명의 의의 발달 단계에서 최상위 수준의 것으 로 증명을 올바르게 이해하기 위해 반드시 필요한 요소 임을 알 수 있었다.

\section{III. 연구방법}

\section{1. 교과서 분석 방법}

현재 중학교에서 지도되고 있는 논증 기하는 2 천년 전에 성인 수학자를 위해 쓴 Euclid 원론의 내용을 중학 교 학생 수준에 맞추어 초등화한 것이며, 공리계까지 지 도하지는 않지만 도형의 몇 가지 기본적인 성질을 받아 들이고 삼각형의 합동조건과 닮음 조건 및 보조선 방법 을 이용하여 연역적으로 추론하도록 하는 Euclid 기하의 틀을 그대로 갖고 있다(우정호, 1998). 이에 본 연구에서 는 교수학적으로 변환된 교과서를 분석해 봄으로써, 연 역 체계가 교과서에 어떻게 반영되고 있는지를 살피고자 한다.

교과서의 연역 체계의 특징을 파악하기 위하여 중학 교 수학 1(류희찬 외, 2009a; 박영훈 외, 2009a; 신항균 외, 2009a, 우정호 외, 2009a, 이준열 외, 2009a)과 중학 교 수학 2(류희찬 외, 2009b; 박영훈 외, 2009b; 신항균 외, 2009b, 우정호 외, 2009b, 이준열 외, 2009b)를 연역 의 흐름에 초점을 맞추어 분석하였다. 익힘책은 교과서 의 기본 내용에 기반한 응용이므로, 익힘책은 분석의 내 용에서 제외하였다. 모든 정리를 분석의 대상으로 삼지 는 않았으며, 예제와 같이 증명이 제시된 것 중 자주 사 용되는 정리를 분석의 대상으로 삼았다. 증명이 제시되
지 않은 정리들을 분석의 대상에서 제외한 것은 이들 정 리가 출발점이 될 수는 없으므로, 교과서 연역 체계의 출발점이 무엇인지를 파악하는데 큰 영향을 주지 못할 것이라는 판단 때문이며, 아울러 연구자의 자의적 해석 을 방지하기 위함이었다.

연역의 흐름을 파악하기 위한 것이므로 정리를 자세 하게 진술하기보다 개략적으로 기술하였으며, '정리 2'의 증명에서 '정리 1'이 사용될 경우 '정리 $1 \rightarrow$ 정리 2 '로 나 타내었다. 한편, 정리 이외에 정의와 같은 것은 분석의 대상에서 제외하였다. 왜냐하면 정의까지 분석의 대상으 로 삼아 무정의 용어의 필요성을 인식하게 하는 것은 중 학교 수학에서 무리라는 판단 때문이다.

2. 순환 논법의 오류 분석 방법

현 교과 체제에서 오류라고 지목되는 순환 논법의 구 체적 예를 찾고 분석해 봄으로써 연역 체계 흐름의 특성 을 명료화하고자 한다. 이를 위해 한국수학교육학회, 대 한수학교육학회, 한국학교수학회의 증명 관련 논문을 검 색하여, 순환논법이라고 생각되는 검사문항이나 예를 추 출하였다. 그러나 이것만으로는 순환논법의 예가 부족하 다고 판단하여 연구자의 수업 경험을 통해 수집한 학생 들의 순환논법의 오류를 추가하였다.

수집한 자료는 먼저 범주별로 분류되었으며, 정리 내 에서인가, 정리 간의 순환 논법의 오류인가가 그 기준이 되었다. 그리고 각 범주 내에서 각 예를 오류의 원인 별 로 구분하여 자료를 정리하였다. 이후 이들이 왜 순환 논법의 오류인지를 분석함으로써, 연역 흐름의 특성을 명확히 하고자 하였다.

\section{IV. 결과 분석 및 논의}

1. 결과 분석

1) 교과서 분석 결과

교과서 연역 체계에 대한 분석 결과, [그림 1]의 연역 흐름도를 얻을 수 있었다. 교과서는 교수학적 변환에 의 해 유클리드 원론의 공리를 그대로 다루지는 않지만, 연 역의 흐름은 서로 닮아 있는 것이 교과서 연역 체계의 주요 골자임을 알 수 있다. 따라서 교과서와 유클리드 원론의 출발점은 다르지만, 연역적 흐름의 측면에서는 
동형이라고 볼 수 있을 것이다.

먼저, 교과서의 연역 흐름을 조망해 봄으로써 연역의 출발점을 파악할 수 있었다. 평행선과 동위각의 성질과 그 역, 그리고 삼각형의 결정조건은 다른 정리 증명의 모태가 되는 정리임을 알 수 있다. 즉, 이들 정리가 교과 서에서 공리로서의 성격을 갖는 정리임을 알 수 있다.

또한 [그림 1]에는 나타나 있지 않지만, 많은 증명에 서 공통인 변이나 공통인 각이 같다는 정리가 사용되고 있음을 알 수 있었다. 이를테면, 이등변삼각형의 성질에 대한 증명에서 삼각형의 합동조건이 이용되는데, 여기서 공통인 변으로서 두 삼각형의 변이 같다는 정리가 사용 되고 있다. 이것은 '동일한 것은 같다'는 공리가 내재해 있는 것으로 볼 수 있을 것이다.

둘째, 연역의 출발점인 정리가 공리로서 도입되는 것 이 아니라, 직관적으로 정당화되고 있다. 평행선과 동위 각의 성질과 그 역은 종이 접기 활동의 확인을 통해 도 입된다. 또 삼각형의 결정조건은 작도 활동을 통한 확인 을 통해 도입되고 있다. 이처럼 연역의 출발점은 공리로 서 도입되지 않고, 직관적 정당화 과정으로서 소개되고 있다.

셋째, 논법의 흐름 상 순환 논법이 나타나지 않고 있 음을 알 수 있다. 현 교과서에서 '이등변삼각형의 두 밑 각의 크기는 같다(이등변삼각형의 성질'는 정리의 증명
에서 수선을 그어 직각삼각형의 합동조건(RHS)을 이용 한 증명은 사용되지 않는다. 왜냐하면 직각삼각형의 합 동조건(RHS)의 증명에서 '이등변삼각형의 두 밑각의 크기는 같다'를 이용하기 때문이다. 따라서 우정호 등의 교과서는 이러한 순환 논법의 오류를 피하기 위해 '이등 변삼각형의 두 밑각의 크기는 같다'는 정리의 증명에서 각의 이등분선을 긋고, SAS합동을 이용한 증명을 제시 하고 있는 것이다. 다음 [그림 2]는 일방향의 논법을 지 향하는 교과서의 연역 흐름과 순환 논법의 오류를 보여 주는 것이다.

이상의 특징 파악을 기반으로 다음의 시사점을 얻을 수 있었다. 먼저, 교과서 연역 체계는 유클리드 원론과 견주어 논리 시발점만 다를 뿐, 연역 흐름의 성격은 일 치하므로 교과서를 통해 연역 체계 이해가 가능할 것이 다. 한편, 이것은 학교수학에서 추구하는 것은 연역의 출 발점 선택이 아니라, 출발점 이후의 흐름이 초점임을 시 사하는 것으로 볼 수 있다.

둘째, 연역의 시발점인 정리가 직관적 정당화를 기반 으로 소개되는 만큼, 교과서의 연역은 직관과 논리 사이 의 선택이 일관되지 못함을 알 수 있다. '두 직선이 한 직선과 만날 때, 동위각의 크기가 같으면 두 직선은 평 행이다'라는 명제는 직관적으로 다루어지지만, '두 직선 이 교차할 때, 맞꼭지각의 크기는 같다'라는 명제는 논리

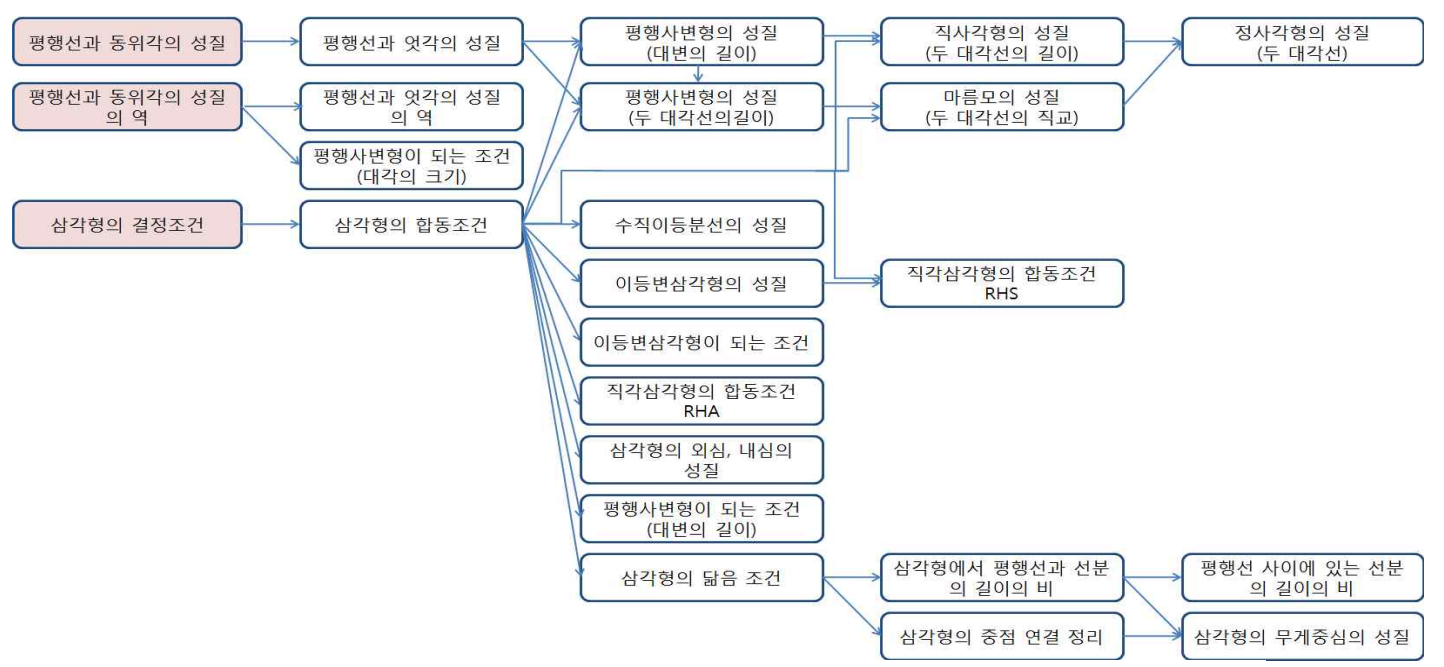

[그림 1] 중학교 1, 2학년 수학 교과서의 연역의 흐름

[Fig. 1] The flow of deduction in middle school textbook on mathematics 
적으로 다루어지고 있다. 김흥기(2001)는 이러한 교과서 연역의 특성 때문에 학생들은 직관과 논리 사이에서 혼 란을 겪는다고 주장한다.

셋째, 연역 흐름도를 그리는 것처럼 연역의 흐름을 조망하는 활동 없이 순환 논법이 나타나지 않는 연역의 특성을 이해하기란 쉽지 않을 것이다. 왜냐하면 학생들 은 한 문제의 증명에도 힘겨워하는 만큼, 전체적 시각에 서 연역의 흐름까지 볼 것을 요구하는 것은 무리이기 때 문이다. 따라서 총체적 시각에서 조망하기 어려운 학생 들에게 이러한 논법의 흐름을 인식하도록 돕기 위한 방 안을 모색할 필요가 있다.
2) 순환 논법의 오류 분석 결과

본 절에서는 현 교육에서 순환 논법으로 지목되는 다 양한 오류의 예를 보여줄 것이다. 제시되는 각 예는 증 명과 관련한 연구 및 연구자가 학교 현장에서 경험한 학 생들이 보인 순환 논법의 오류를 수집한 것이다. 이들을 크게 내부적 순환 논법과 외부적 순환 논법으로 분류하 였다. 여기서 내부적 순환 논법은 정리 내의 순환 논법 이며, 외부적 순환 논법은 정리 간의 순환 논법을 의미 한다.
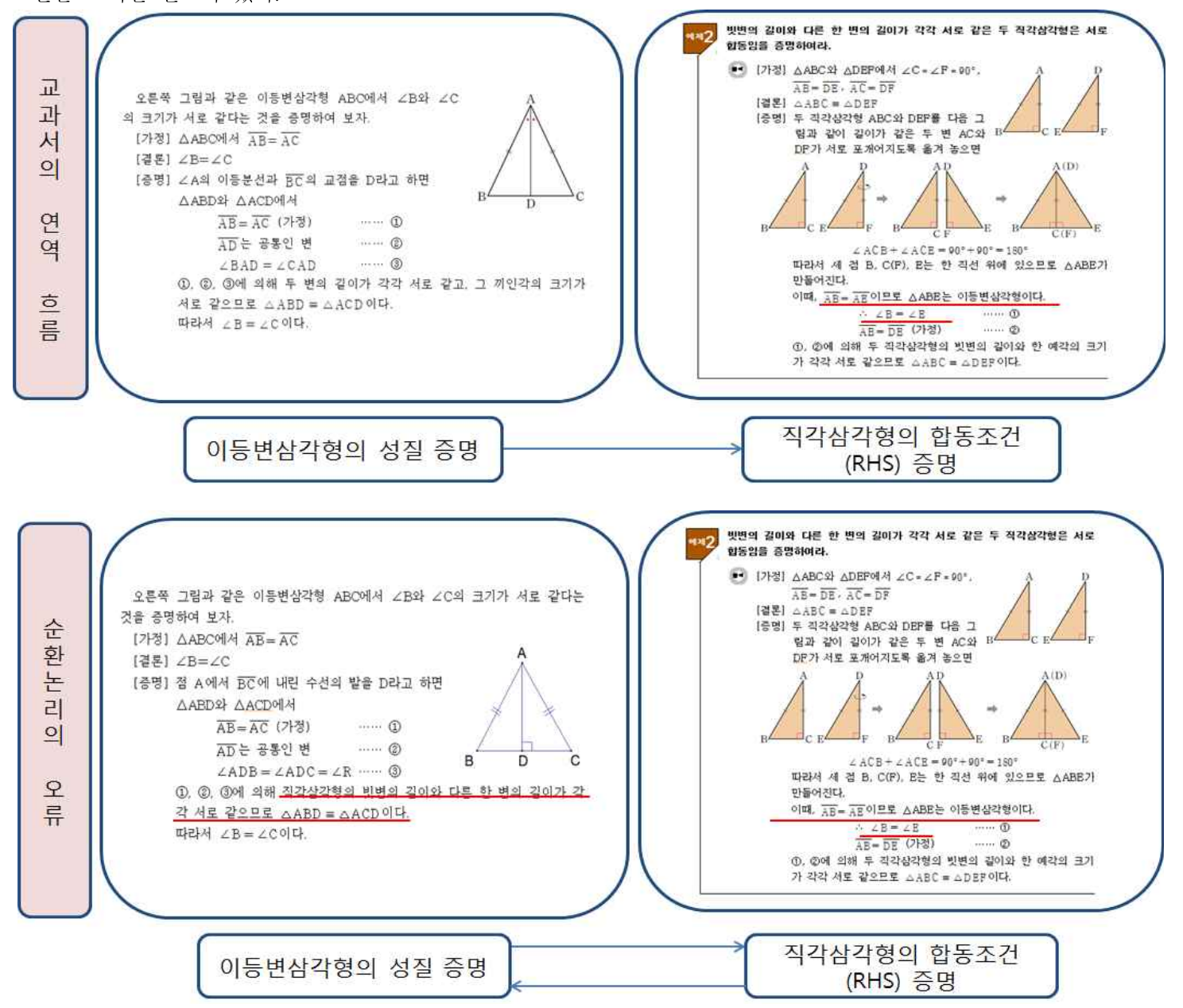

[그림 2] 교과서의 연역 흐름과 정리 사이의 순환 논법의 오류

[Fig. 2] The flow of deduction in textbook and the error of circular argument between theorems 
(1) 내부적 순환 논법

(1) 증명해야 할 결론을 증명에 이용하는 경우

다음은 '이등변삼각형의 두 밑각의 크기는 같다'는 정 리의 증명에서 증명해야 할 결론을 증명에 이용하여 내 부적 순환 논법의 오류를 범한 경우이다(류성림, 1998a).

'이등변삼각형의 두 밑각의 크기는 같다'는 것을 다음과 같이 증명하였다.

증명) $\overline{\mathrm{AB}}=\overline{\mathrm{AC}}$ 인 $\triangle \mathrm{ABC}$ 에서 $\angle \mathrm{A}$ 의 이등분선 과 밑변 $\mathrm{BC}$ 와의 교점을 $\mathrm{D}$ 라 한다. 그러면 $\triangle \mathrm{ABD}$ 와 $\triangle \mathrm{ACD}$ 에서

$\overline{\mathrm{AB}}=\overline{\mathrm{AC}}, \angle \mathrm{BAD}=\angle \mathrm{CAD}$, $\angle \mathrm{B}=\angle \mathrm{C}$ 이다.

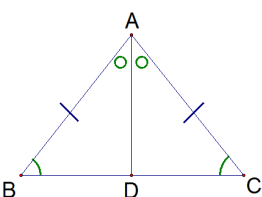

따라서 한 변과 그 양끝각의 크기가 각각 같으

므로 $\triangle \mathrm{ABD} \equiv \triangle \mathrm{ACD} \quad \therefore \angle \mathrm{B}=\angle \mathrm{C}$

이 논리 과정은 증명해야 할 $\angle \mathrm{B}=\angle \mathrm{C}$ 를 증명에 이용하여 순환 논법의 오류를 범한 경우이다.

다음은 박은조, 방정숙(2005)이 연구에서 제시한 문항 이다. 명제 '임의의 삼각형의 내각의 총합은 항상 $180^{\circ}$ 이다'에 대해 5가지 증명을 제시하고, 그 증명에 대해 평 가하는 문항인데, 이 중 다음의 증명은 증명하고자 하는 것이 함의된 내부적 순환 논법의 오류에 해당한다.

<민준의 증명>

나는 $\angle b=65^{\circ}$ 인 이등변삼각형을 그렸다.

이등변삼각형의 두 밑각의 크

기는 같으므로,

$\angle a=180^{\circ}-2 \angle b$

$\therefore \angle a=50^{\circ}$

$\therefore \angle c=180^{\circ}-(\angle a+\angle b)=65^{\circ}$

이등변삼각형의 두 밑각의 크기는 같으므로, $\angle c=\angle b$ 이다. $\therefore a+b+c=180^{\circ}$

따라서 주어진 명제는 참이다.

이 증명에서 이미 삼각형의 내각의 합은 $180^{\circ}$ 라는 것을 이용하여 $\angle a$ 의 크기와, $\angle c$ 의 크기를 구하고 있 으므로 이것은 순환 논법의 오류에 해당한다.
이와 같이 증명에서 최종적 도착점인 결론을 증명에 서 이용하는 순환 논법의 오류는 많은 학생들이 범하는 오류 중 하나이다. 류성림(1998a)은 중학교 2, 3학년 학 생들이 대상으로 앞서 제시한 '이등변삼각형의 두 밑각 의 크기는 같다'는 정리 증명을 제시하고 학생들이 논법 의 불합리성을 이해하는지 검사하였는데, 정답률이 2 학 년 41\%, 3학년 56\%로 나타났으며, 이것은 많은 학생들 이 추론의 구성에 대한 이해도가 결여되어 있음을 보여 준다.

\section{(2) 시각적 특징에 의존한 내부적 순환 논법}

시각적 특징에 의존한 내부적 순환 논법은 시각적 특 징에 의존하여 연역적 체계상 후행해서 나와야 할 것이 선행하여 나타나는 경우를 일컫는다. 많은 학생들이 시 각적 기하 표현의 일반성을 이해하지 못하여 다음과 같 은 순환 논법의 오류를 범하기도 한다.

아래 그림에서 반직선 $\mathrm{OP}$ 는 $\angle \mathrm{AOB}$ 의 이등분 선이고, 두 점 $\mathrm{A}, \mathrm{B}$ 는 각각 점 $\mathrm{P}$ 에서 각의 양변 에 내린 수선의 발이다. 이 그림을 이용하여 각의 이등분선 위의 한 점에서 각의 양변까지의 거리는 같음을 증명하여라.

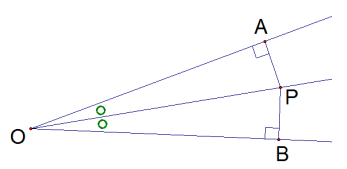

증명) $\overline{\mathrm{OA}}=\overline{\mathrm{OB}}$ 이고 $\angle \mathrm{AOP}=\angle \mathrm{BOP}$

그리고 $\overline{\mathrm{OP}}$ 는 공통이므로

$\triangle \mathrm{OAP} \equiv \triangle \mathrm{OBP}$ (SAS합동)

$\therefore \overline{\mathrm{AP}}=\overline{\mathrm{BP}}$

이 경우 $\overline{\mathrm{OA}}=\overline{\mathrm{OB}}$ 라는 조건이 성립한다는 근거를 찾을 수 없음에도 시각적인 면에 의존하여 범하게 되는 오류이다. $\overline{\mathrm{AP}}=\overline{\mathrm{BP}}$ 라는 결론에 도달하기 위해서는 두 삼각형의 합동을 이용해야 하는데, 두 삼각형이 합동임 으로 인해 등장해야 할 $\overline{\mathrm{OA}}=\overline{\mathrm{OB}}$ 라는 조건을 두 삼각 형이 합동임을 보이는 과정에서 이용함으로써 순환 논법 의 오류가 빚어진 것이다. 


\section{(2) 외부적 순환 논법}

[그림 2]에 제시된 순환 논법의 오류가 곧 외부적 순 환 논법으로, 외부적 순환 논법은 정리 간의 증명에서 빚어질 수 있는 오류이다. 정리 1 의 증명에서 정리 2 가 이용되었다면, 정리 2 의 증명에서 정리 1 을 사용할 수 없다. 그러나 정리 2 의 증명에서 정리 1 을 이용한다면 그것은 외부적 순환 논법의 오류가 된다. 한편, 정리 1 의 증명을 정리 2가 이용되지 않는 다른 것으로 제시할 경 우에는 정리 2 의 증명에서 정리 1 을 이용하는 것도 상관 없는 것이 될 것이다. 그 동안 순환 논법의 오류가 몇몇 연구에서 제시되었지만, 이들 연구의 대다수는 내부적 순환 논법의 오류에 주목했을 뿐 외부적 순환 논법의 오 류에는 주목하지 못했던 것으로 생각된다(류성림, 1998a; 박은조, 방정숙, 2005). 다음은 수학 학업 성적이 우수한 학생들이 서술형 평가에서 답한 자료에서 발췌한 것들이 다.

다음 그림과 같이 원의 중심 $\mathrm{O}$ 가 호 $\mathrm{AB}$ 에 대 한 원주각 $\angle \mathrm{APB}$ 의 내부에 있을 때, $\angle \mathrm{APB}$ $=\frac{1}{2} \angle \mathrm{AOB}$ 임을 증명하시오. (단, $\overleftrightarrow{\mathrm{PO}}$ 와 원의 교 점을 $\mathrm{C}$ 라 한다.)

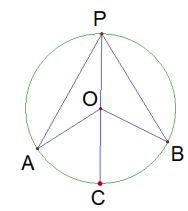

증명) $\overline{\mathrm{BO}}$ 를 연장하여 원과 만나는 점을 $\mathrm{D}$ 라고 한다면 $\angle \mathrm{ODA}=\angle \mathrm{OAD}$ 이다.

$$
\begin{aligned}
\angle \mathrm{AOB} & =\angle \mathrm{ODA}+\angle \mathrm{OAD} \text { (외각) } \\
& =2 \angle \mathrm{ODA} \\
\angle \mathrm{ODA} & =\angle \mathrm{APB} \text { (원주각) } \\
\therefore \angle \mathrm{AOB} & =2 \angle \mathrm{APB} \\
\therefore \angle \mathrm{APB} & =\frac{1}{2} \angle \mathrm{AOB}
\end{aligned}
$$

이것은 원주각이 중심각의 절반임을 보이는 과정이며, 특히 원의 중심이 원주각의 내부에 있는 경우에 대한 것 이다. 그런데 위의 증명에서 '같은 호에 대한 원주각의 크기는 동일하다'는 정리를 이용하고 있다. 이것은 외부
적 순환 논법의 오류에 해당한다. 왜냐하면 '같은 호에 대한 원주각의 크기는 동일하다'는 정리가 '원주각이 중 심각의 절반'이라는 정리를 이용하여 증명되기 때문이다. 즉, 위의 증명은 '(원주각 $=1 / 2$ 중심각) $\rightarrow$ (같은 호에 대한 원주각의 크기는 동일하다)'라는 연역 체계의 흐름을 인 식하지 못할 경우 빚어질 수 있는 순환 논법의 오류이 다. 다음의 두 가지 증명 역시 외부적 순환 논법의 오류 에 해당한다.

다음 그림과 같이 원 $\mathrm{O}$ 의 지름의 양 끝점 $\mathrm{A}$, $\mathrm{B}$ 에서 그은 접선과 점 $\mathrm{P}$ 에서 그은 접선의 교점을 각각 $\mathrm{C}, \mathrm{D}$ 라고 할 때, $\angle \mathrm{COD}$ 의 크기는?

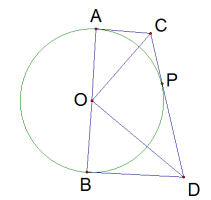

\begin{tabular}{l|l}
\hline \multicolumn{1}{c|}{ 증명 1} & \multicolumn{1}{|c}{ 증명 2} \\
\hline$\triangle \mathrm{CAO}$ 와 $\triangle \mathrm{CPO}$ 에서 & $\triangle \mathrm{CAO}$ 와 $\triangle \mathrm{CPO}$ 에서 \\
$\overline{\mathrm{CA}}=\overline{\mathrm{CP}}, \overline{\mathrm{CO}}$ 는 공통 & $\overline{\mathrm{CA}}=\overline{\mathrm{CP}}, \overline{\mathrm{CO}}$ 는 공통, \\
$\angle \mathrm{CAO}=\angle \mathrm{CPO}=90^{\circ}$ & $\overline{\mathrm{OA}}=\overline{\mathrm{OP}}$ 이므로 \\
$\triangle \mathrm{CAO} \equiv \triangle \mathrm{CPO}$ & $\triangle \mathrm{CAO} \equiv \triangle \mathrm{CPO}$ \\
$(\mathrm{RHS}$ 합동 $)$ & $(\mathrm{SSS}$ 합동 $)$ \\
$\triangle \mathrm{CBO}$ 와 $\triangle \mathrm{DPO}$ 에서 & $\triangle \mathrm{CBO}$ 와 $\triangle \mathrm{DPO}$ 에서 \\
$\overline{\mathrm{BD}}=\overline{\mathrm{PD}}, \overline{\mathrm{OD}}$ 는 공통 & $\overline{\mathrm{BD}}=\overline{\mathrm{PD}}, \overline{\mathrm{OD}}$ 는 공통, \\
$\angle \mathrm{OBD}=\angle \mathrm{OPD}=90^{\circ}$ & $\overline{\mathrm{OB}}=\overline{\mathrm{OP}}$ 이므로 \\
$\triangle \mathrm{OBD} \equiv \triangle \mathrm{OPD}$ & $\triangle \mathrm{OBD} \equiv \triangle \mathrm{OPD}$ \\
$(\mathrm{RHS}$ 합동 $)$ & $(\mathrm{SSS}$ 합동 $)$ \\
$2 \angle \mathrm{COP}+2 \angle \mathrm{POD}=180$ & $2 \angle \mathrm{COP}+2 \angle \mathrm{POD}=180$ \\
$\angle \mathrm{COP}+\angle \mathrm{POD}=90^{\circ}$ & $\angle \mathrm{COP}+\angle \mathrm{POD}=90^{\circ}$ \\
$\angle \mathrm{COD}=90^{\circ}$ & $\angle \mathrm{COD}=90^{\circ}$ \\
\hline
\end{tabular}

위의 두 가지 증명은 그 과정에서 $\overline{\mathrm{CA}}=\overline{\mathrm{CP}}$ 라는 근 거를 사용하고 있는데, 이는 외부적 순환 논법의 오류에 해당한다. $\overline{\mathrm{CA}}=\overline{\mathrm{CP}}$ 라는 것은 '원 밖의 한 점에서 그 원에 그은 두 접선의 길이는 같다'는 사실로부터 성립하 는 사실이다. 그런데 '원 밖의 한 점에서 그 원에 그은 두 접선의 길이는 같다'는 정리의 증명은 다음과 같다.

원 $\mathrm{O}$ 밖의 한 점 $\mathrm{P}$ 에서 그 원에 그을 수 있는 
접선은 오른쪽 그림과 같이 2 개이다. 이때 두 접점 을 각각 $\mathrm{A}, \mathrm{B}$ 라고 할 때, 선분 $\mathrm{PA}$ 또는 선분 $\mathrm{PB}$ 의 길이를 점 $\mathrm{P}$ 에서 원 $\mathrm{O}$ 에 그은 접선의 길이라 고 한다. 이제 $\overline{\mathrm{PA}}=\overline{\mathrm{PB}}$ 임을 알아보자.

그림의 $\triangle \mathrm{PAO}$ 와 $\triangle \mathrm{PBO}$ 에서

$$
\begin{aligned}
& \angle \mathrm{PAO}=\angle \mathrm{PBO}=90^{\circ} \\
& \overline{\mathrm{OA}}=\overline{\mathrm{OB}} \text { (반지름) }
\end{aligned}
$$

$\overline{\mathrm{OP}}$ 는 공통인 변이므 로 $\triangle \mathrm{PAO} \equiv \triangle \mathrm{PBO}$ 이다. 따라서 $\overline{\mathrm{PA}}=\overline{\mathrm{PB}}$ 임을 알 수 있다.

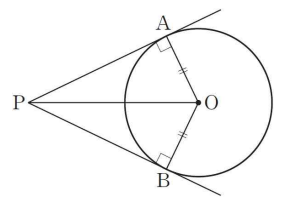

이상의 증명을 보면 증명 과정에서 생성되는 두 삼각 형이 RHS 합동이라는 직각삼각형의 합동조건이 이용 되고 있음을 알 수 있다. 그런데 위의 두 증명 과정에서 는 두 삼각형이 합동임으로 인해 성립하게 되는 '두 접 선의 길이가 같다'는 사실을 두 삼각형이 합동임을 증명 하는데 이용하고 있음을 알 수 있다. 따라서 위의 증명 은 위의 논법의 흐름에서는 외부적 순환 논법에 해당하 게 된다. 물론 '원 밖의 한 점에서 그 원에 그은 두 접선 의 길이가 같다'는 사실에 대한 증명이 위와 같이 이루 어지지 않는다면 그것은 외부적 순환 논법이 아닐 것이 다.

이상의 논의로부터 정리 내에서나 정리 간에서나 순 환 논법은 오류로써 취급되는 만큼, 정리 내·외적으로 연역의 흐름은 일방향을 지향하는 성격을 갖고 있음을 알 수 있다. 즉, 정리 내에서도 증명해야 할 것을 근거로 서 이용하지 못하는 것과 마찬가지로, 정리 간에서도 정 리 1 증명의 근거로서 작용한 정리2에 대한 증명에서 정 리1을 근거로서 사용할 수 없는 것이다. 이것은 연역 체 계의 흐름이 정리 내·외적으로 일관됨을 보여주는 것이 다.

\section{2. 논의: 바람직한 지도 방향}

1) 연역의 시발점에 대한 필요성 인식: 공리 설정

유클리드 원론을 교수학적 변환 없이 그대로 지도해 야 하는 것인가? 인지 발달 수준이 높지 않은 중학생에 게 공리, 공준에 기반한 엄격한 형식적인 연역 체계를
지도하는 것은 바람직하지 않을 것이다. 오히려 공리적 접근으로 가기 위한 준비의 과정으로서, 교과서의 연역 체계를 지도하는 것이 바람직하다고 생각된다. 교과서 연역 체계의 인식은 향후 공리 연역적 체계의 인식을 위 한 디딤돌로서의 역할을 할 것이다.

따라서 증명에서 근거로서 무엇을 선택해야 하는지를 명확히 하기 위하여 현 수학에서 수립된 공리 연역적 접 근보다, 오히려 교과서 연역 체계에서 이들 근거를 분명 히 할 필요가 있다. 이에 본 연구에서는 교과서 연역의 출발점인 평행선과 동위각의 성질과 그 역, 그리고 삼각 형의 결정조건, '동일한 것은 같다'를 공리로 택하고 이 를 바탕으로 지도하는 방안을 제안한다. 이는 강미광 (2010)의 연구에서도 찾아볼 수 있으며, 그는 삼각형의 결정조건을 매개체로 사용하지 말고 삼각형의 합동조건 을 직접적 공리로서 도입하자고 주장하였다.

사실 이와 같은 정리들이 교과서에 직관적으로 다루 어져 왔던 것은 증명이 쉽지 않기 때문이며, 아울러 이 들의 증명을 위해서는 근원이 되는 공리가 필요하기 때 문이라고 생각된다. 이를테면, 평행선에서 동위각의 크기 는 같다는 정리의 증명을 위해서는 평행선 공리가 다루 어져야 한다. 이것은 유클리드의 공리에서 출발할 뿐 아 니라, 중학생이 이해하기에 다소 어려운 논지를 펼치고 있기에 교수학적 관점에서 변환을 꾀하여 직관적으로 다 룬 것으로 생각된다.

증명에서 진정으로 지도해야 하는 것은 유클리드 원 론 그 자체라기보다 유클리드 원론에 깃든 공리적 사고 라고 생각된다. 공리적 사고는 유클리드의 공리를 그대 로 다루지 않는다고 해서 퇴색되는 것은 아닐 것이다. 연역 체계의 완벽함을 추구하는 과정에서 연역의 원천이 필요함을 인식하게 되고, 이를 공리로써 선택한 것이지 처음부터 공리가 있어왔던 것은 아니다. 따라서 현 교과 서에서 유클리드의 5 공준, 5 공리를 따르지 않는다고 해서 연역 체계의 근본정신을 훼손하게 되는 것은 아닐 것이다.

이에 본 연구에서는 교과서 연역의 출발점을 공리로 서 택하는 교수를 제안하는 것이다. 이를 통해 공리적 사고의 근간을 이해하는 기틀을 마련해야 할 것이다. 공 리라는 용어를 조심스럽게 사용해야 할 것이며, 연역의 원천의 필요성을 인식하는 계기로 삼아야 할 것이다. 교 
수학적으로 공리라는 용어의 도입이 불합리하다고 생각 되면, 공리 대신 논리의 출발점으로서 직관적으로 다루 어야 할 정리라고 명시함으로써 연역의 출발점이 필요함 을 인식시켜야 할 것이다. 어딘가에는 증명 없이 인정하 고 받아들여야 하는 연역의 출발점이 존재해야 함을 인 식할 수 있게 해야 할 것이다.

수학에서 공리 선택의 본질은 자유스러움에 있다. 때 문에 현대 수학은 공리 선택의 자유스러움에 기반하여 다양한 수학적 결과를 창출해 가고 있다. 따라서 유클리 드의 공리, 공준만이 정답일 수는 없으며, 우리가 유클리 드에서 배워야 할 점은 연역의 출발점에 대한 필요성과 연역의 흐름인 것이다. 따라서 본 연구에서는 공리 선택 의 자유스러움을 전제하여 교수학적 변환을 꾀하고자 하 는 것이다. 이때 공리는 직관에 기반3)하여 선택되며, 이 를 통해 수학이 갖는 자유스러움과 연역의 출발점에 대 한 필요성을 재고해 보게 하자는 것이다.

2) 일방향의 연역 흐름에 대한 인식: 순환 논법의 오 류 활용

교과서 연역의 흐름은 순환 논법을 거부하고 일방향 의 흐름을 지향한다. 본 연구에서는 이와 같은 연역 흐 름 이해를 돕는 방안에 대해 논의하고자 한다.

전술하였듯, 한 문제의 증명도 버거운 학생에게 연역 체계 전체의 조망을 요구하는 것은 무리일 것이다. 따라 서 연역 흐름의 인식을 돕기 위해서는 연역 체계 전체를 조망하지 않고도 연역 흐름을 이해할 수 있는 방안이 요 구된다.

이에 본 연구에서는 순환 논법의 오류를 활용할 것을 제안한다. 사실 오류는 그것을 통해 인지적 장애를 극복 하게 할 수 있는 매개체로 이용될 수 있는 것이다. 오류 수정을 위한 대표적 교수·학습 모형으로 순환 학습 모형, 개념 변화 학습 모형이 있으며, 이들은 공통적으로 오류 에 의한 인지적 불균형이 초래됨으로써, 인지적 조절을 통해 오류 수정과 개념 교정의 과정으로 요약된다(최보 영, 2005 재인용). 이것은 오류를 단순히 잘못된 것으로 인식하기보다, 학습에 적극 이용해야할 선 개념으로 인식 하고 있음을 보여준다. 수학 학습에서 이와 같은 관점에

3) 직관에 기반하여 공리를 선택하는 것은 누구나 쉽게 받아들 이고 용인할 수 있는 내용을 공리로써 선택하자는 것이다.
서 오류의 적극적 이용을 제안한 학자로 Borasi(1996)가 있으며, 오류를 이용한 탐구 학습을 제안하였다.

그는 오류를 학습과정에 적극적으로 이용하는 방법은 학생 자신이 잘못된 학습과정에서 인지적 갈등을 느꼈던 지 아니면 그렇지 않던 간에 문제를 제기해 봄으로써 인 지적 갈등을 의식하게 하여야 한다고 주장한다. 이를 테 면 잘못된 문제해결 결과를 보고 학생이 잘못되었음을 안다면 왜 잘못되었는가에 대한 질문을 한다. 무엇인 잘 못인지를 모른다면 '어떤 경우에 그러한 절차를 사용했 는가?' 또는 '그것이 옳다면 다른 성질들은 어떻게 성립 되는가?'와 같은 질문을 통해 주변 개념들을 조사하게 만듦으로써 모순에 부덪히도록 한다. 모순된 상황에서 학생은 인지적 갈들을 느끼고, 기존의 개념을 수정해야 할 필요성을 알게 될 것이다(최지선, 2003 재인용).

본 연구에서는 연역 체계의 흐름에 대한 이해를 돕기 위하여 순환 논법의 오류를 이용한 탐구 학습을 제안한 다. 먼저, 내부적 순환 논법의 오류를 제시하여, 이것이 잘못된 것인지 아니면 잘 된 것인지를 판단하게 한다. 그리고 잘못인지를 안다면 그것이 왜 잘못인지를 탐구하 게 하며, 잘못인지를 모른다면 다른 성질들도 이와 같은 방법으로 증명할 수 있는지를 물어봄으로써 주변 개념을 조사하게 만든다. 이러한 과정을 통해 내부적 순환 논법 의 오류를 이용함으로써 증명 과정에서 어떤 것이 추론 의 근거로서 사용될 수 있는지를 명확히 하고, 논리적 당위성을 확보하는 일이 중요함을 인식하게 해야 할 것 이다. 궁극적으로는 한 정리에 대한 증명에서 추론의 구 성에 대한 이해에 도달할 수 있도록 해야 할 것이다.

그러나 내부적 순환 논법의 오류를 인식함으로써 정 리들 간의 연역 체계의 흐름을 인식하게 되는 것은 아니 다. 하나의 정리 내에서 일방향으로 진행되는 연역의 흐 름은 정리들 간에도 그대로 재현된다. 그러나 이러한 사 실을 인식하기란 쉽지 않아 보인다. 정리 내에서 성립하 는 연역의 흐름을 정리들 사이로 전이하기 위해서는 외 부적 순환 논법을 이용한 탐구 학습이 도움이 될 수 있 을 것이라 생각된다.

이것 역시도 외부적 순환 논법을 제시하고, 이것이 잘못된 것인지 아니면 잘 된 것인지를 판단하게 한다. 그리고 잘못인지를 안다면 그것이 왜 잘못인지를 탐구하 게 하며, 잘못인지를 모른다면 다른 성질들도 이와 같은 


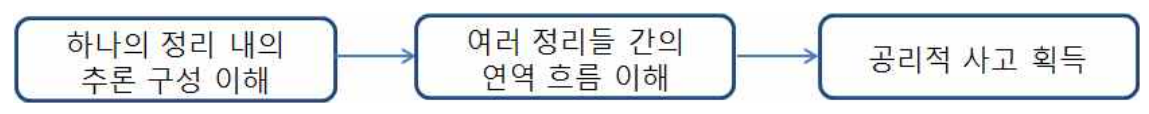

[그림 3] 연역 체계 이해의 발달 단계

[Fig. 3] The developmental stage on the understanding of deduction system

방법으로 증명하였을 경우에 대해 물어봄으로써 주변 개 념을 조사하게 만든다. 이러한 과정을 통해 논리 연역의 체계가 갖는 일방향의 성격을 이해할 수 있도록 해야 할 것이다. 궁극적으로 연역 체계의 흐름의 특징을 이해함 으로써 공리적 사고를 위한 기반을 마련해야 할 것이다.

구체적으로 본 연구에서 제안한 내부적·외부적 순환 논법의 예를 이용한 다음의 가상 수업을 생각해 볼 수 있을 것이다.

<내부적 순환 논법 활용>

내부적 순환 논법의 (1) 증명해야 할 결론을 증명에 이용하는 경우에 나타난 예 '이등변삼각형의 두 밑각의 크기는 같다는 정리'에 대한 증명을 제시한다. 내부적 순 환 논법이 발생한 이 오류를 탐구하게 함으로써 학생들 에게 정리 내부에서 나타나는 논법의 흐름 이해를 위한 단초를 마련할 수 있을 것이다.

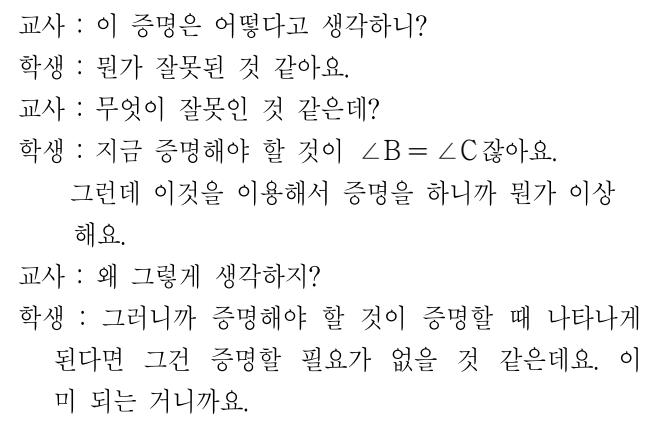

\section{<외부적 순환 논법 활용>}

먼저, [그림 2] 순환 논리의 오류에 나타난 '이등변삼 각형의 두 밑각의 크기는 같다'는 정리에 대한 증명을 제시한다. 이와 동시에 직각삼각형의 합동조건에 대한 [그림 2]의 증명을 제시한다. 외부적 순환 논법이 나타나 는 이 오류를 탐구하게 함으로써 학생들에게 정리 외부 에서 나타나는 논법의 흐름 이해를 위한 단초를 마련할
수 있을 것이다.

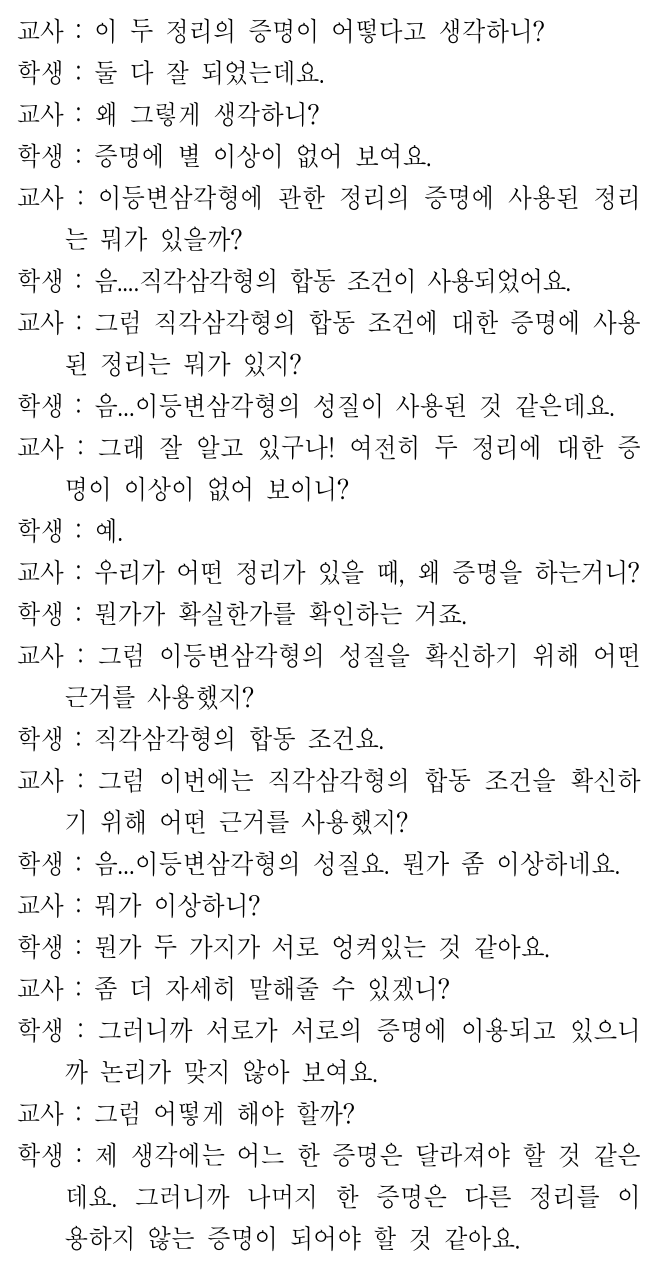

교과서 연역 흐름이 일방향을 지향함에도 그 특징이 두드러진 것은 아니므로 인식에 어려움이 따른다. 이에 본 연구에서는 내부적·외부적 순환 논법의 오류를 이용 한 탐구학습을 통해 교과서 연역에 함의된 특징 인식의 
기회를 제공하고자 하는 것이다. 교과서의 체제 변형을 꾀하기보다, 교과서 연역에 함의된 특성 인식을 돕는 교 수 방안을 제안한다. 구체적으로 실제 수업에서 순환 논 법의 오류를 제공하여, '이것이 오류인지 아닌지', '왜 오 류라고 보아야 하는지'에 대해 토의해 봄으로써, 교과서 연역 흐름에 함의되었지만 인식하기 어려운 연역 흐름의 특징까지 학습할 수 있는 기회를 제공해야 할 것이다.

이러한 논의에 따르면, 연역 체계에 대한 이해의 발 달 단계를 [그림 3]과 같이 구분할 수 있을 것이다.

\section{V. 결론 및 제언}

연역 체계의 이해는 다음 두 가지의 문제로 구분될 수 있다. 연역 체계의 출발점은 무엇인가? 연역 체계의 논법 흐름은 어떠한가?

본 연구에서는 이 두 문제에 초점을 두고 연역의 출 발점에 대한 필요성과 일방향의 연역 흐름의 인식을 돕 기 위하여, 교과서의 연역 체계를 분석하여 다음의 결과 를 얻을 수 있었다.

교과서는 유클리드의 공리에 기반하고 있지는 않지만, 일방향을 지향하는 연역의 흐름의 측면에서는 유클리드 원론과 동일한 연역 체계를 구축하고 있었다. 특히, 평행 선과 동위각의 성질과 그 역, 그리고 삼각형의 결정조건 이 연역의 출발점인 정리로서 작용하고 있었으며, 이들 은 직관적으로 정당화되고 있었다. 비록 공리의 선택에 서 유클리드 원론과는 차별되지만, 일방향의 연역의 흐 름은 동일하였다.

한편, 현 교육 체계에서 오류로 지목되는 순환 논법 의 여러 예를 찾고, 이들을 분석하여 다음의 결과를 얻 을 수 있었다.

순환 논법이 오류는 크게 내부적 순환 논법과 외부적 순환 논법으로 분류할 수 있었다. 연역 체계는 내부적으 로 증명해야 할 결론과 결론을 보이기 위해 필요한 근거 가 있다. 이들 사이의 관계 이해는 추론 구성 이해의 주 요 요소라고 할 수 있다. 이들 근거가 증명해야 할 결론 과 혼재되어 증명에서 사용될 경우, 이것은 내부적 순환 논법의 오류에 해당된다. 그러나 정리 내부에서 이와 같 은 논법의 흐름은 정리들 간에도 그대로 유지되는데, 이 것은 외부적 순환 논법의 오류이다. 이처럼 본 연구에서
는 순환 논법을 두 가지로 분류하여 논의하였는데, 이를 통해 정리 내·외적으로 일방향을 지향하는 연역 흐름의 일관된 특성을 명료화하였다.

마지막으로 본 연구에서는 연역 체계의 성격을 이해 하는 바람직한 교수 방향 두 가지를 제안하였다. 전술하 였듯 수학에서 공리 선택의 본질은 자유스러움에 있다. 순수 수학에서 (1), (2), (3)이 공리인 어떤 체계에 대해, 어떤 수학자가 (a)를 이용하여 (1)을 이끌어내고 (a)와 (2), (3) 각각이 독립적이면 기존 공리는 (a), (2), (3)으로 바뀌 게 된다. 이것은 수학에서 공리가 고정된 것이 아니라, 변화할 수 있는 것임을 보여준다. 본 연구는 이러한 공 리 선택의 자유스러움에 기반하여, 현 교과서의 연역의 출발점을 공리로서 도입하는 방안을 제안하였다.

그러나 이와 같은 공리 선택이 교과서에서 다루어지 는 성질들로 이루어지는 만큼, 교수학적 변환에 의해 조 정된 이러한 공리 하에서는 존재하는 수학적 성질을 모 두 다루기는 어렵게 될 것이다. 즉, 유클리드 공리로는 증명 가능하지만, 새로운 공리로는 증명이 불가능한 정 리가 나타날 가능성을 지니게 된다. 본 연구에서 제안한 방법은 공리 선택의 자유스러움을 경험하고 연역의 출발 점을 인식하는 장점이 있지만, 연역 체계의 완벽성이 불 완전해질 수 있는 한계를 지니게 되는 것이다. 따라서 이런 점을 주지하여 조심스럽게 지도해야 할 것이다.

한편, 일방향의 연역 흐름은 연역 체계 전체를 조망 해보지 않고서 이해하기란 쉽지 않다. 이에 본 연구에서 는 그 대안의 한 가지로 순환 논법의 오류에서 찾고자 하였다. 오류의 순기능적 측면에 주목하여 순환 논법의 오류를 이용하여 탐구해 봄으로써 논법 흐름의 주요 특 징인 순환 논법이 발생하지 않는 논법의 흐름을 인식시 키고자 하는 것이다.

먼저, 내부적 순환 논법의 오류를 탐구하게 함으로써 정리 내의 연역 흐름을 이해할 수 있도록 해야 할 것이 다. 그리고 외부적 순환 논법을 제시하고 탐구하게 함으 로써, 연역의 체계가 갖는 일방향의 성격을 이해할 수 있도록 해야 할 것이다.

이러한 지도 방향을 통해, 궁극적으로 연역 체계의 흐름의 특징을 이해함으로써 공리적 사고를 획득하기 위 한 기반을 조성하고 마련해야 할 것이다. 


\section{참 고 문 헌}

강문봉 (1992). 분석법에 대한 고찰. 대한수학교육학회 논문집 2(2), 81-93.

Kang, M.J. (1992). An educational study on analysis. Journal of the Korea Society of Educational Studies in Mathematics 22), 81-93.

강문봉 (1993). Lakatos의 수리철학의 교육적 연구. 박 사학위논문, 서울대학교.

Kang, M.J. (1993). An educational study on the Lakato's philosophy of Mathematics. Doctoral dissertation, SNU.

강미광 (2010). 유클리드 기하학에서 삼각형의 합동조건 의 도입 비교, 수학교육 49(1), 53-65.

Kang, M.K .(2010). A study on the comparison of triangle congruence in euclidean geometry. The Mathematical Education 4Q1), 53-65.

김흥기 (2001). 중학교 수학에서 증명을 위한 공리 취급 에 관한 연구, 수학교육 40(2), 291-315.

Kim, H.K. (2001). A note on treatment of axioms for proof in middle school mathematics. The Mathematical Education 4(2), 291-315.

나귀수 (1998). 증명의 본질과 지도 실제의 분석-중학교 기하단원을 중심으로-. 박사학위논문, 서울대학교.

Na, G.S. (1998). An analysis of the nature of proof and practice of proof edcuation: focused on the middle school geometry. Doctoral dissertation, SNU.

나귀수 (2009). 분석법을 중심으로 한 기하 증명 지도에 대한 연구, 수학교육학연구 19(2), 185-206.

Na, G.S. (2009). Teaching geometry proof with focus on the analysis. The Journal of Education Research in Mathematics 192), 185-206.

류성림 (1998a). 수학교육에서 '증명의 의의'에 관한 연 구, 수학교육 37(1), 73-85.

Ryu, S.R. (1998a). A study on the meaning of proof in mathematics education. The Mathematical Education 371), 73-85.

류성림 (1998b). 피아제의 균형화 모델에 의한 증명의 지도 방법 탐색. 박사학위논문, 한국교원대학교.

Ryu, S.R. (1998b). A study on the teaching method of proofs based on piagetian equilibration model. Doctoral dissertation, KNUE.

류성림 (1998c). 전형식적 증명의 의미와 교수학적 의미
에 관한 연구, 대한수학교육학회지 논문집 8(1), 313-326.

Ryu, S.R. (1998c). A study on the meaning of preformal proof and its didactical significance. Journal of the Korea Society of Educational Studies in Mathematics 8(1), 313-326.

류희찬, 류성림, 한혜정, 강순모, 제수연, 김명수, 천태선, 김민정 (2009a). 중학교 수학 1 . 서울: 미래엔 컬처그 룹.

Ryu, H.C., Ryu, S.R., Han, H.J., Kang, S.M., Je, S.Y., Kim, M.S., Cheon, T.S., \& Kim, M.J. (2009a). Middle school mathematics 1. Seoul: Mirae N Culture.

류희찬, 류성림, 한혜정, 강순모, 제수연, 김명수, 천태선, 김민정 (2009b). 중학교 수학 2. 서울: 미래엔 컬처그 룹.

Ryu, H.C., Ryu, S.R., Han, H.J., Kang, S.M., Je, S.Y., Kim, M.S., Cheon, T.S., \& Kim, M.J. (2009b). Middle school mathematics 2. Seoul: Mirae N Culture.

박영훈, 여태경, 김선화, 심성아, 이태림, 김수미 (2009a). 중학교 수학 1 . 서울: 천재문화.

Park, Y.H., Ye, T.G., Kim, S.H., Sim, S.A., Lee, T.R., \& Kim, S.M. (2009a). Middle school mathematics 1. Seoul: Chunjaemunhwa.

박영훈, 여태경, 김선화, 심성아, 이태림, 김수미 (2009b). 중학교 수학 2. 서울: 천재문화.

Park, Y.H., Ye, T.G., Kim, S.H., Sim, S.A., Lee, T.R., \& Kim, S.M. (2009b). Middle school mathematics 2. Seoul: Chunjaemunhwa.

박우석 (2008). 제르멜로와 공리적 방법, 논리연구 11(2), $1-56$.

Park, W.S. (2008). Zermelo and the axiomatic method. The logical research 11(2), 1-56.

박은조, 방정숙 (2005). 수학 교사들의 증명에 대한 인 식, 한국학교수학회논문집 8(1), 101-116.

Park, E.J., \& Pang, J.S. (2005). A survey on mathematics teachers' cognition of proof. Journal of the Korea School Mathematics Society \&(1), 101-116.

신항균, 이광연, 윤혜영, 이지현 (2009a). 중학교 수학 1. 서울: 지학사.

Sin, H,G., Lee, K.Y., Yoon, H.Y., \& Lee, J.H. (2009a). Middle school mathematics 1. Seoul: Jihaksa. 신항균, 이광연, 윤혜영, 이지현 (2009b). 중학교 수학 2. 
서울: 지학사

Sin, H,G., Lee, KY., Yoon, H.Y., \& Lee, J.H. (2009b). Middle school mathematics 2. Seoul: Jihaksa.

우정호 (1998). 학교 수학의 교육적 기초. 서울: 서울대 학교출판부.

Woo, J.H. (1998) The educational base of school mathematics. Seoul: SNU Publishing.

우정호, 박교식, 박경미, 이경화, 김남희, 임재훈, 박인, 이영란, 고현주, 김은경 (2009a). 중학교 수학 1. 서 울: 두산동아.

Woo, J.H., Park, G.S., Park, G.M., Lee, G.H., Kim, N.H., Lim, J.H., Park, I., Lee, Y.R., Ko, H.J., \& Kim, E.G. (2009a). Middle school mathematics 1. Seoul: Dusandonga.

우정호, 박교식, 박경미, 이경화, 김남희, 임재훈, 박인, 이영란, 고현주, 김은경 (2009b). 중학교 수학 2. 서 울: 두산동아.

Woo, J.H., Park, G.S., Park, G.M., Lee, G.H., Kim, N.H., Lim, J.H., Park, I., Lee, Y.R., Ko, H.J., \& Kim, E.G. (2009b). Middle school mathematics 2. Seoul: Dusandonga.

유윤재 (2004). 공리의 문화적 의미, 한국수학사학회지 17(1), 119-125

Yoo, Y.J. (2004). The cultural meaning of axioms. Journal for History of Mathematics 171), 119-125.

이준열, 최부림, 김동재, 송영준, 윤상호, 황선미 (2009a). 중학교 수학 1 . 서울: 천재교육.

Lee, J.Y., Choi, B.R., Kim, D.J., Song, Y.J., Yoon, S.H., \& Hwang, S.M. (2009a). Middle school mathematics 1. Seoul: Chunjae education.

이준열, 최부림, 김동재, 송영준, 윤상호, 황선미 (2009b). 중학교 수학 2. 서울: 천재교육.

Lee, J.Y., Choi, B.R., Kim, D.J., Song, Y.J., Yoon, S.H., \& Hwang, S.M. (2009b). Middle school mathematics 2. Seoul: Chunjae education.

이지현 (2011). 중학교 기하에서의 공리와 증명의 취급 에 대한 분석, 수학교육학연구 21(2), 135-148.

Lee, J.H. (2011). An analysis on the treatment of axiom and proof in middle school mathematics. The Journal of Education Research in Mathematics 21(2), 135-148.

조정수, 이정자 (2006). 증명보조카드를 활용한 중학생의 증명지도에 관한 연구, 한국학교수학회논문집 9(4), 521-538.

Jo, J.S. \& Lee, J.J. (2006). A study on teaching mathematical proofs of the middle school students using the 'proof assisted cards', Journal of the Korea School Mathematics Society $9(4), 521-538$

최보영 (2005). '식의 계산' 단원에서 수학 학습부진아의 오류 분석과 교정에 관한 연구: 고등학교 1학년을 대 상으로. 석사학위논문, 이화여자대학교.

Choi, B.Y. (2005). A study of error analysis and correction toward students who are underachievers in calculation of numerical formula: on the basis of the first year of the high school student. Master's thesis, EWU.

최지선 (2003). 중등학교 수학 학습에서 나타나는 오개 념에 대한 고찰. 석사학위논문, 서울대학교.

Choi, J.S. (2003). A study on the misconceptions in the learning of the secondary school mathematics. Master's thesis, SNU.

國宗進 (1992). 圖形의 證明 指導. 東京: 明治圖書株式會 社.

Almeida, D. (1996). Justifying and proving in the mathematics classroom. Philosophy of Mathematics Education Newsletter 9. http://www-didactique. imag.fr/preuve/Resumes/Almeida/POME9Almeida.ht $\mathrm{ml}$

Bell, A. W. (1976). A study of pupils proofexplanations in mathematical situations, Educational Studies in Mathematics, 7, 23-40.

Bell, A. W. (1979). The learning of process aspects of mathematics, Educational Studies in Mathematics, 10, 361-387.

Borasi, R. (1996). Reconceiving Mathematics Instruction: A Focus on errors, New York: Ablex.

Dodes, I. A. (1966). Mathematics: Its structure, logic and method. In E. G. Begle(Ed.), The role of axiomatics and problem solving in mathematics. Boson, MA: Ginn and Company.

Fawcett, H. P. (2006). 증명의 본질(장경윤, 류현아, 한 세호 역). 서울: 경문사. (원저는 1966년 출판).

Fishbein, E., \& Kedem, I. (1982). Proof and certitude in the development of mathematical thinking. In. Vermandel(Ed). Proceedings of the Sixth International Conference for the Psychology of Mathematical Education. Antwerp: PME. 
Hanna, G. (2000). Proof, explanation and exploration: An overview. Educational Studies in Mathematics, 44(1), 5-23.

Harel, G., \& Sowder, L.(1998). Types of students' justifications. Mathematics Teacher, 91(8), 670-675.

Heath, T. (1981). A History of Greek Mathematics, vol. II. New York: Dover.

Lehman, H. (1980). An Examination of Imre Lakatos's Philosophy of Mathematics. The Philosophical Forum, 12, 33-48.

Martin, W. G., \& Harel, G. (1989). Proof Frames of Preservice Elementary Teachers, Journal for Research in Mathematics Education, 20, 1.

Schoenfeld, A. H. (1994). Reflections on doing and teaching mathematics. In A. H. Schoenfeld(Ed.), Mathematical thinking and problem solving (pp.53-70). Hillsdale, NJ: Erlbaum.

Sierpinska, A. \& Lerman, S. (1996). Epistemologies of Mathematics and of Mathematics Education. In Alan J. Bishop(Eds.), International Handbook of Mathematics Education. Dordrecht: Kluwer Academic, 827-876.

Williams, E. (1990). An Investigation of Senior High School Students' Understanding of the Nature of Mathematical Proof, Journal for Research in Mathematics Education, 11, 3. 


\title{
A study on understanding the deduction system in the proof
}

\author{
Kang, Jeong Gi \\ Namsan Middle School, Chang-Won 642-110, Korea \\ E-mail : jeonggikang@gmail.com \\ Roh, Eun Hwan ${ }^{+}$ \\ Department of Mathematics Education, Chinju National University of Education, Jinju 660-756, Korea \\ E-mail : idealmath@gmail.com; ehroh@cue.ac.kr
}

To help students understand the deduction system in the proof, we analyzed the textbook on mathematics at first. As results, we could find that the textbook' system of deduction is similar with the Euclid' system of deduction. The starting point of deduction is different with each other. But the flow of deduction match with each other. Next, we searched for the example of circular argument and analyzed. As results, we classified the circular argument into two groups. The first is an internal circular argument which is a circular argument occurred in a theorem. The second is an external circular argument which is a circular argument occurred between many theorems. We could know that the flow of deduction system is consistent in internal-external dimension. Lastly, we proposed the desirable teaching direction to help students understand the deduction system in the proof.

* ZDM Classification : D53

* 2000 Mathematics Subject Classification : 97D50

* Key words : Understanding the deduction system, Cognition for the Necessity of starting point of deduction, Circular argument

+ Corresponding author 